\title{
BUTIR-BUTIR PANCASILA DALAM NASKAH SUNDA KUNO ABAD XVI MASEHI
}

\section{Elis Suryani Nani Sumarlina, ${ }^{1}$ Undang Ahmad Darsa, ${ }^{2}$ Rangga Saptya Mohamad Permana ${ }^{3}$ dan Ike Rostikawati Husen ${ }^{4}$}

${ }^{1,2}$ Fakultas Ilmu Budaya, Universitas Padjadjaran, Jl. Raya Bandung-Sumedang KM. 21 Jatinangor, 456363 ${ }^{3}$ Fakultas Ilmu Komunikasi, Universitas Padjadjaran, Jl. Raya Bandung-Sumedang KM. 21 Jatinangor, 456363 ${ }^{4}$ Fakultas Ilmu Kedokteran Universitas Padjadjaran, Jl. Raya Bandung-Sumedang KM. 21 Jatinangor, 456363 E-mail: elis.suryani@unpad.ac.id; undang.a.darsa@unpad.ac.id; rangga.saptya@unpad.ac.id;ike.husen@unpad.ac.id

\begin{abstract}
ABSTRAK. Naskah sebagai dokumen budaya, sampai saat ini belum begitu dikenal oleh masyarakat secara menyeluruh. Padahal isi yang terkandung di dalamnya bisa dikaji dari berbagai disiplin ilmu secara multidisiplin. Salah satunya naskah Sunda yang mengungkap butir-butir Pancasila, yang bermanfaat untuk ilmu sosial politik, ilmu hukum dan ketatanegaraan, maupun ilmu komunikasi. Sebagaimana kita ketahui bahwa Pancasila sebagai landasan hukum NKRI masih tetap kokoh hingga kini, dan senantiasa bersemayan dalam denyut jantung serta nadi setiap insan masyarakat Indonesia, meskipun beberapa kali diuji eksistensinya. Itu sebabnya, kita senantiasa mengenang hari lahir dan kesaktian Pancasila. Tulisan ini bertujuan mengungkap gagasan butir-butir Pancasila yang terungkap dalam naskah Sanghyang Siksakanda 'Ng Karesian (SSK), Amanat Galunggung (AG), dan Sanghyang Raga Dewata (SRD). Metode penelitian yang digunakan deskriptif analisis komparatif serta kritik teks, historiografi tradisional, dan hermeneutik, untuk mengungkap gagasan Pancasila yang terpendam dalam naskah Sunda Kuno abad XVI Masehi. Butir-butir Pancasila dijabarkan melalui Panca Tata Gatra, terdiri atas: 1) Percaya kepada Sang Pencipta yang menguasai alam semesta; 2) Tindakan dan perilaku manusia yang harus adil, bijaksana, dan beradab; 3) Unsur alam semesta, yakni tanah, air, angin, cahaya, dan angkasa, yang harus bersatu; 4) Perekonomian diimplementasikan melalui mata pencaharian hidup sebagai petani, ahli perang, bangsawan termasuk alim ulama, dan raja/pemimpin pemegang tahta kekuasaan; dan 5) Tiga penentu kebijakan dalam keadilan berbangsa dan bernegara. Panca Tata Gatra dimaksud, sejalan dengan kelima butir Pancasila yang kini digunakan sebagai dasar negara Republik Indonesia.
\end{abstract}

Kata kunci: Butir-butir Pancasila; naskah; Sunda kuno; abad XVI masehi; kearifan lokal.

\section{PANCASILA ITEMS IN XVI CENTURY AD ANCIENT SUNDANESE MANUSCRIPT}

\begin{abstract}
Until now, manuscripts as cultural documents have not been well known by the public as a whole. Even though the contents contained in it can be studied from various disciplines in a multidisciplinary manner. One of them is the Sundanese manuscript which reveals the points of Pancasila, which is useful for socio-political science, law and state administration, as well as communication science. As we know that Pancasila as the legal basis for the Republic of Indonesia is still solid until now, and always resides in the heartbeat and pulse of every human being in Indonesian society, even though its existence has been tested several times. That's why, we always remember the birthday and the magic of Pancasila. This paper aims to reveal the ideas of Pancasila as revealed in the texts of Sanghyang Siksakanda 'Ng Karesian (SSK), Amanat Galunggung (AG), and Sanghyang Raga Dewata (SRD). The research method used is descriptive comparative analysis as well as textual criticism, traditional historiography, and hermeneutics, to reveal the idea of Pancasila which is hidden in the ancient Sundanese script in the XVI century AD. The points of Pancasila are described through the Panca Tata Gatra, consisting of: 1) Belief in the Creator who controls the universe; 2) Human actions and behavior that must be fair, wise, and civilized; 3) The elements of the universe, which are earth, water, wind, light, and space, which must be united; 4) The economy is implemented through livelihoods as farmers, war experts, nobles including religious scholars, and kings/leaders holding the throne of power; and 5) Three policy makers in national and state justice. The Panca Tata Gatra is in line with the five points of Pancasila which are now used as the basis of the Republic of Indonesia.
\end{abstract}

Keywords: Pancasila items; manuscript; Ancient Sundanese; XVI century AD; local wisdom

\section{PENDAHULUAN}

Teks adalah muatan naskah, sebagai peninggalan budaya nenek moyang masa lalu, yang ditengarai berisi data dan fakta berupa ide, gagasan, falsafah hidup, dan kearifan lokal lainnya yang meliputi tujuh unsur budaya, yang eksistensinya isinya masih dapat dirasakan dan berguna saat ini. Isi teks naskah dimaksud, gagasan tentang pandangan hidup, sistem pemerintahan, sistem pembagian kekuasaan, etika, komunikasi politik, dan kepemimpinan beserta sikap dan karakter yang 
menyertainya. Untuk itu, harus ada kiprah dan usaha untuk menggali, meneliti, mengkaji, serta mengenalkan kembali agar diketahui dan dimotivasi untuk ikut serta memelihara, melestarikan, bahkan mengembangkannya, melalui kajian ilmiah terhadap naskah beserta isinya.

Selama ini, yang awam terhadap naskah, beranggapan bahwa ide, gagasan, pandangan hidup, terutama sistem pemerintahan dan pembagian kekuasaan yang ada saat ini berasal dari teori Montesque melalui 'trias politica', yang dikenal dengan istilah eksekutif, legeslatif, dan yudikatif. Padahal, naskah Sunda kuno abad XVI Masehi, yang berjudul Fragmen Carita Parahiyangan dan Sanghyang Siksakandang Karesian, mengungkapkan bahwa sistem pemerintahan dan pembagian kekuasaan masyarakat Sunda masa lampau itu berdasarkan Tri Tangtu Di Buana, yang meliputi Prabu, Rama, dan Resi, yang pada hakikatnya sama dengan teori Montesque tersebut (Suryani NS, dkk., 2021).

Gagasan dan pemikiran tentang dasar negara bangsa Indonesia yang dikenal dengan 'Pancasila', yang selama ini kita ketahui hanya dari naskah Jawa melalui Mpu Tantular dan Mpu Prapanca. Padahal, dalam naskah Sunda kuno pun, ide, pandangan hidup, dan makna dari Pancasila dimaksud sudah ada sejak abad ke XVI Masehi, melalui teks naskah yang menggunakan bahan dari lontar, aksara Sunda Kuno, dan bahasa Sunda kuno, hanya berbeda istilahnya saja. Sehubungan dengan hal tersebut, tulisan ini berusaha mengungkap dan menyajikan ide dan gagasan tentang pandangan/falsafah hidup Pancasila sebagai dasar negara Republik Indonesia. Naskah Sunda kuno dalam hal ini punya andil dalam menyumbangkan kebhinekaan kebudayaan yang ada di Indonesia.

Penelitian dan pengkajian naskah Sunda Kuno, baik yang berkaitan dengan masalah konsep kepemimpinan, etika, politik, sistem pemerintahan, komunikasi, beserta aspek lainnya yang berkaitan dengan gagasan dasar negara (Pancasila), terungkap karya Ekadjati dan Darsa (2007). Kajian-kajiannya berupa transliterasi, rekonstruksi, dan terjemahan berjudul Kosmologis Sunda dalam Naskah Sanghyang Raga Dewata, dsb. cukup membantu penelitian naskah Sunda kuno. Di samping itu, garapan filologis lainnya, meski hanya berupa transkripsi dan terjemahan, yang dilakukan oleh Atja, Saleh Danasasmita, Ayatrohaedi, dan Undang Ahmad Darsa yang berkaitan dengan naskah Sanghyang Siksakandang Karesian, Kawih Paningkes, Tjarita Parahiyangan, Sewaka Darma, Amanat Galunggung, dan lainnya, menjadi acuan dalam mengungkap kata dan makna dalam penelitian kami (Darsa, dkk., 2019).

\section{METODE}

Bisa dikatakan banyak model penelitian yang dikemukakan oleh beberapa ahli. Sehubungan dengan hal tersebut, metode dan teknik penelitian filologi untuk mengungkap data butir-butir Pancasila yang ada dalam naskah Sunda Kuno abad XVI Masehi, dalam tulisan ini mengimplementasikan metode deskriptif analisis komparatif digunakan untuk mendeskripsikan data yang ditemukan dalam teks naskah, melalui tahap pengumpulan data, penyeleksian data tahap awal, pemilihan data tingkat utama atau gradasi, anaisis data, dan penyajian data. Metode kajian filologi, meliputi kajian kodikologis dan kajian tekstologis.

MetodepenelitiandeskriptifanalisisKomparatif merupakan metode yang dianggap cocok untuk penulisan artikel ini. Melalui pencatatan, penuturan, penafsiran, penganalisisan serta pembandingan data, antara budaya Sunda secara multidisiplin dengan ilmu-ilmu lainya. Pemilihan metode kritik teks dalam filologi disesuaikan dengan kondisi naskah yang dijadikan obyek penelitian, yang sasarannya berupa suntingan teks, dan didasarkan atas edisi naskah tunggal dan naskah jamak. Berkaitan dengan

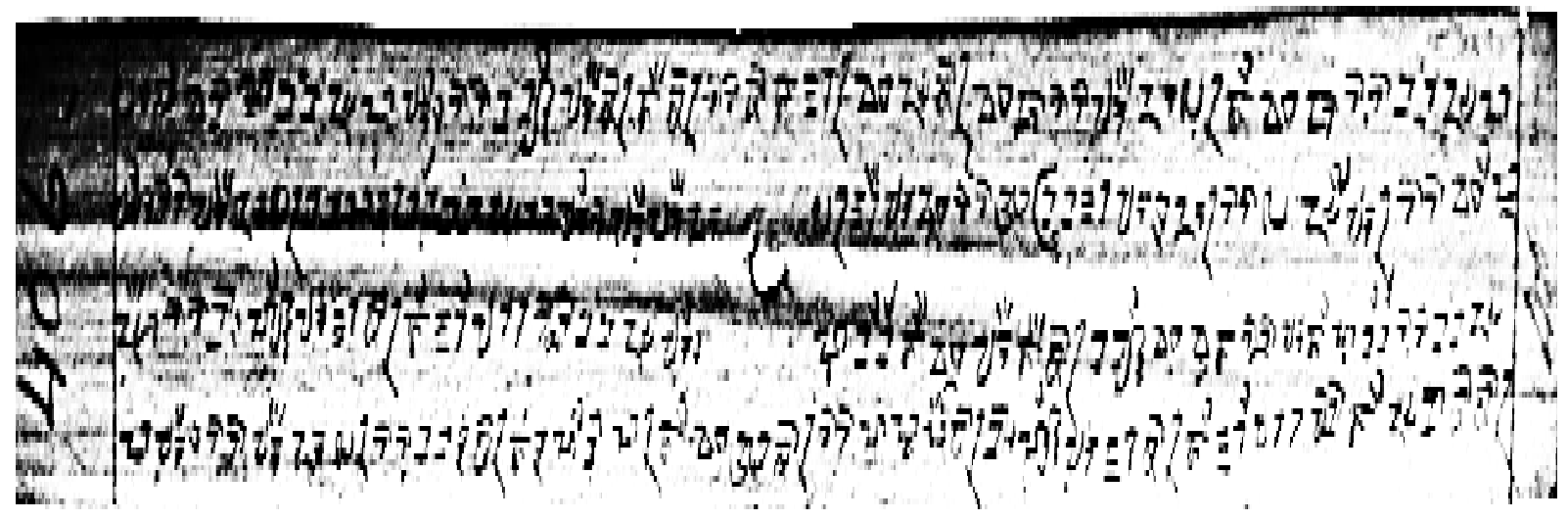

Source: Personal Documentation, 2009

Gambar 1. Naskah Fragmen Carita Parahyangan 
kajian ini, isi teks naskah yang dijadikan dasar edisi ditelusuri dan dikaji berdasar sudut pandang budaya secara kosmologi (Darsa, 2019).

Kajian kodikologis berkaitan dengan seluk beluk naskah, yag meliputi identifikasi naskah berdasarkan katalog, melalui judul, ukuran, bahan, aksara, bahasa, genre, silsilah naskah, pemilihan naskah yang akan disunting, serta digunakan dan disajikan dalam artikel sesuai tema. Sedangkan kajian isi dilakukan secara tekstologis, melalui transliterasi teks, rekonstruksi teks, edisi teks dan terjemahan, yang dilanjutkan dengan menganalisis teks hasil terjemahan, untuk mengungkap isi teks naskah, meliputi ide, gagasan, para pemangku kebijakan di masyarakat pada saat naskah itu ditulis atau disalin, khususnya yang berkaitan dengan butirbutir Pancasila dalam naskah Sunda Kuno Abad XVI Masehi. Teknik penelitian studi pustaka membaca/ mendapatkan katalog naskah (katalogisasi), tentang ide dan gagasan tentang dasar negara atau Pancasila. Dengan demikian, penelusuran naskah di masyarakat beserta informasi lisan pun akan terdokumentasi dengan baik. (Suryani NS, 2021)

\section{HASIL DAN PEMBAHASAN}

\section{Kosmologis Dalam Teks Naskah Sunda Kuno}

Data-data yang berkaitan dengan butirbutir Pancasila dalam teks naskah Naskah SRD, didapati data kosmologis Sunda, berkaitan dengan terciptanya alam semesta yang diciptakan oleh Sanghyang Tunggal, yang meliputi tatasurya yang harus bersatu, sebagaimana disebutkan dalam Panca Tata Gatra dalam naskah Sanghyang Siksa Kandang Karesian, yang merupakan butir sila ketiga. Dalam tataran kosmologis tersebut ada juga adanya faktor angin dan api. Terungkap pula nama-nama dewa, yang berjumlah lima, yakni: Dewa Brahma, Dewa Wisnu, Dewa Siwa, Iswara, dan Mahadewa, yang diberi tugas mengendalikan Batara Basuki yang ada di bumi dan Batara Baruna yang ada di lautan, demi keseimbangan jagat raya atau alam semesta.

Gambaran kosmologis Sunda di masa lalu, pada dasarnya sama halnya asumsi kita di masa kini, meski tidak persis seratus persen. Menurut naskah $S R D$, manusia dilihat sebagai mikrokosmosnya alam semesta. Manusia senantiasa dituntut untuk melakukan serta menjalankan segala ajaran Maha Pencipta (Sanghyang Darma). Jika manusia melakukan hal yang sudah ditentukan, disebut sebagai manusia ideal, dan kelak bisa masuk/mencapai nirwana atau surga. Dalam Kosmologis masyarakat Sunda pada lampau, segala kosmis terklasifikasi menjadi lima unsur asasi, yakni madhab opat kalima pancer) 'empat madhab, dan yang kelima merupakan pusatnya'. Urutan arahpun tetap, yakni: selatan, barat, utara, timur, pusat. Begitu juga dengan penyebutan nama hari, yang diklasifikasikan menjadi manis, pahing, pon, wage, kaliwon, yang tidak bisa ditukar, karena berkaitan dengan perhitungan hari baik dan buruk seseorang dalam melakukan sebuah pekerjaan. Hal seperti ini masih dilakukan oleh masyarakat adat, baik masyarakat adat di Jawa Barat maupun masyarakat adat Kanekes Baduy di Banten. Antara manusia yang berada di buana kecil dan alam sebagai buana besar ada harmonisasi yang saling memengaruhi (Suryani NS, 2021).

Teks SRD menjelaskan lebih lanjut, bahwa adanya perubahan nama Batara Guru yang berdiam di sebuah gunung bernama Kahyangan. Namun tidak dijelaskan secara rinci, apakah Kahyangan yang dianggap sebagai Sawarga Loka atau di bumi. Gambaran kosmologis dalam $S R D$, andai dicermati, ada keterkaitan dengan kosmos filsafat Pancasila menurut Bakker (1983). Sila kedua sampai sila kelima merupakan dimensi horisontal. Sementara itu, keempat sila tersebut mengacu kepada sila pertama.

\section{Butir-butir Sila Pancasila dalam Naskah Sunda Kuno}

Pancasila sebagaimana dikemukakan dalam uraian sebelumnya, yang tidak diragukan lagi kekuatan dan kehebatannya, meskipun beberapa kali diuji eksistensinya, hingga kini Pancasila tetap kokoh dan menjiwai bangsa Indonesia. Itu sebabnya, kita senantiasa mengenang hari lahir dan kesaktian Pancasila setiap tahunnya, agar Pancasila senantiasa menjiwai setiap gerak dan langkah rakyat Indonesia, tidak terlepas dari keyakinan dan kepercayaan masing-masing setiap insan manusia Indonesia, berdasarkan agamanya.

Butir-butir Pancasila yang terdapat dalam naskah Sunda kuno, sebenarnya dapat dikaji dari sudut pandang berbagai perspektif ilmu. Bukan hanya dikaji dari sudut pandang budaya, tetapi dari bidang ilmu lainnya secara multidisiplin, seperti sosial, politik, etika, filsafat, ilmu komunikasi, maupun hukum. Namun ada kendala, karena tidak mudah mengungkap isi naskah, jika tidak menguasai aksara, bahasa, dan budaya tempat naskah itu ditulis.

Butir-butir Pancasila dalam teks Kuno, dikenal dengan sebutan Panca Tata Gatra, terkuak lewat teks naskah SSK bagian III, yang terdiri atas: 1) Adanya lima kewajiban untuk meyakini dan percaya terhadap Sang Manon, sebagai pencipta jagat raya, yang berbunyi Sembah Ing Hulun di Sanghyang Panca Tatagatra ; 2) Perilaku dan tindakan manusia yang sesuai dengan moral, serta pertimbangan keadilan 
dan kebijaksanaan, yang dalam teks naskah disebut Panca Gati, Jaga Rang Dek Luput Ing Na Pancagati Sangsara; 3) selubung jagat raya, yang harus bersatu, dan tidak bisa dipisahkan satu sama lain untuk kelangsungan hidup di dunia, meliputi: angkasa, angin, cahaya, air, dan tanah (akasa, bayu, téja, apah, pratiwi), yang dalam teks naskah disebut Panca Byapara Kusika; 4) Perekonomian diimplementasikan melalui mata pencaharian hidup sebagai petani, ahli perang, bangsawan termasuk alim ulama, dan raja/pemimpin pemegang tahta kekuasaan 5) Tiga penentu kebijakan dalam keadilan berbangsa dan bernegara. Panca Tata Gatra dimaksud, sejalan dengan kelima butir Pancasila yang kini digunakan sebagai dasar negara Republik Indonesia (Charliyan, 2015).

Teks SSK bagian IV menjabarkan butir-butir Pancasila, yang berkaitan dengan kahyangan penghuni para dewa lokapala sebagai pelindung dan pendamai jagat raya, disesuaikan dengan letak dan kedudukan arah mata angin, yang memiliki warnanya masingmasing, dikenal dengan sebutan lima kemakmuran seluruh negeri, dan dijaga oleh para dewa dimaksud, dengan sebutan dalam teks naskah Sanghiyang Wuku Lima Di Bwana, Halimpu Ikang Désa Kabéh, yakni, yakni: 1) Arah wétan 'timur' (Purwa), berwarna putih, dan bertempat di kahyangan, diduduki oleh Isora; 2) Sebelah Daksina (kidul) 'selatan', berwana merah, ditempati Hyang Brahma; 3) Sebelah Pasima (kulon) 'barat', berwarna kuning, ditempati Hyang Mahadewa; 4) Sebelah Utara (kalér 'utara'), berwarna hitam, ditempati Hyang Wisnu; 5) Arah Madya 'tengah', berwarna aneka macam, ditempati Hyang Siwa (Suryani NS, dkk., 2021)

\section{Gambaran Kosmologis Butir-Butir Sila Pancasila Dalam SRD}

Filsafat Pancasila yang dikemukakan Barker (1993) selaras dengan kosmologis yang terkuak dalam teks naskah $S R D$, berkaitan dengan adanya dimensi horisontal antara sila kedua, ketiga, keempat, dan sila kelima, manusia menempati keempat sila dalam Pancasila. Manusia bersifat monodualisme, yang berlaku untuk semua, yang secara substantif bahwa sila kedua sampai kelima dimaksud berpusat terhadap sila pertama. Menurut teks naskah SRD secara substantif bahwa semua yang ada di jagat raya ini berpusat kepada Sanghyang Tunggal (Tuhan Yang Mahaesa), pencipta semua makhluk yang ada di bumi ini, sebagaimana terungkap dalam data-data yang sudah dikaji. (Gambar 2)

Butir-butir Pancasila sepatutnya dapat diejewantahkan dan dipraktekkan dalam kehidupan seharihari oleh seluruh rakyat dari Sabang sampai Merauke, sebagaimana dilaksanakan oleh masyarakat Sunda pada masa silam, melalui sistem pemerintahan dan sistem pembagian kekuasaan, yang disebut Tri Tangtu Di Buana. Pembagian kekuasaan Sunda dimalsud terungkap dalam teks naskah berjudul Fragmen Carita Parahiyangan dan SSK, seperti yang berlaku pada sistem pemerintahan sekarang, yang dikenal dengan istilah trias politica, karya Montecque, yang dalam sistem pembagian kekuasaan di masyarakat Sunda, terdiri atas Prebu, yang dalam teks naskah SSK disebut Sang Prebu, Sang Rama, dan Sang Resi. Prebu sebagai eksekutif, saat ini dipegang oleh presiden, sebagai pemimpin roda pemerintahan pusat. Ia harus memiliki sifat dan karakter teguh (ngagurat batu). Harus menjalankan hukum dengan adil. Berkarakter saciduh metu saucap nyata "apa yang dikatakan, itu juga yang dilakukan' sesuai dengan koridor yang benar dan terarah.

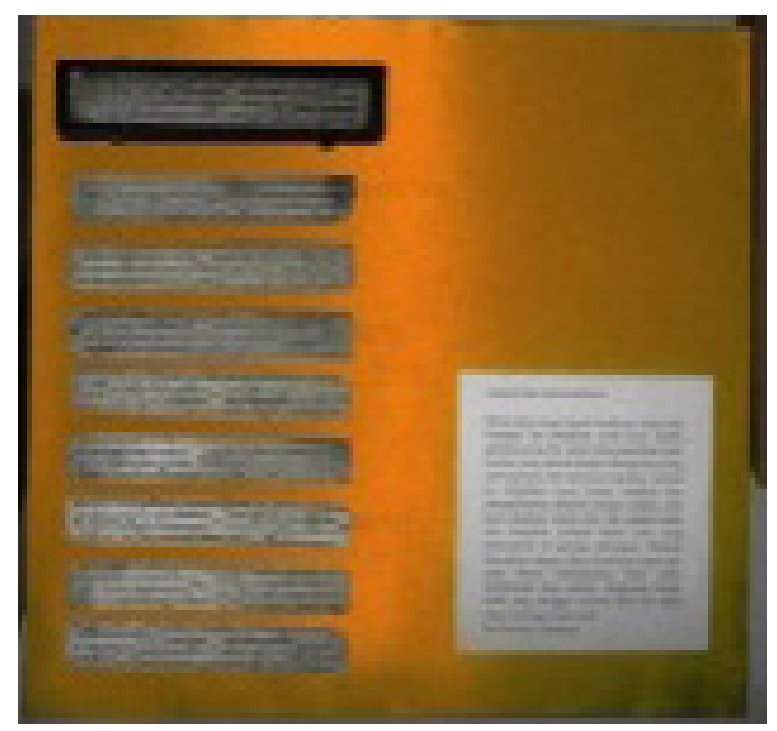

Gambar 2. Naskah Sanghyang Raga Dewata

Golongan Rama bertindak layaknya legislatif atau Dewan Perwakilan Rakyat saat ini. Ia mewakili rakyat, merupakan golongan yang dipercaya dan 'dituakan' serta bertanggung jawab, memiliki karakter ngagurat lemah 'berwatak adil bijaksana, karena membuat dan menentukan peraturan serta perundangundangan yang berlaku, dan harus dilaksanakan serta diimplementasikan' di masyarakat. Di dalamnya termasuk keluarga, tokoh, dan pemuka masyarakat. Peran keluarga sangat penting karena berperan dalam pendidikan informal, yang mencetak sumber daya manusia yang andal. Dalam hal ini peran ibu sebagai ujung tombak ikut menentukan pendidikan karakter anak-anaknya, dengan tidak mengesampingkan peran ayah tentunya. Makanya kekuatan masyarakat sangat bergantung pada daya tahan keluarga. Peran pendidikan formal dan nonformal juga menunjang dan mendukung terwujud tidaknya kemajuan suatu negara. Ini juga ada kaitannya dengan butir-butir Pancasila sebagai landasan dan dasar hukum NKRI. 
Golongan Resi sebagai yudikatif. Yang termasuk golongan Resi, dalam hal ini adalah sekelompok orang cerdik cendekia, para pendidik, termasuk tokoh agama dan para alim ulama, serta orang-orang yang mampu memerdayakan hukum, yang di masa kini dipegang oleh Mahkamah Agung, Golongan Resi memiliki karakter menyejukkan atau Ngagurat Cai dalam masalah hukum dan peradilan. Para cerdik cendekiawan ikut serta membina serta membimbing masyarakat demi berkembangnya kualitas SDM yang unggul, lebih maju, bermanfaat, dan berdaya guna.

Salah satu tugas golongan Resi harus menjadi suri tauladan atau panutan yang mampu membimbing, mengayomi, dan mengarahkan masyarakat ke kehidupan yang lebih maju dan sejahtera. Andai kita simak, sistem pemerintahan dan pembagian kekuasaan seperti Tri Tangtu di Buana ini, masih dapat kita lihat dalam sistem pemerintahan dan pembagian kekuasaan di masyarakat Kanekes Baduy Provinsi Banten. Masyarakat Sunda pun mengenal istilah sistem pemerintahan dan pembagian kekuasaan yang masih berlaku di Masyarakat Kampung Naga Kecamatan Salawu Kabupaten Tasikmalaya, dengan sebutan "Tri Tangtu di Bumi", terdiri atas tatawilayah 'wilayah', tatawayah 'waktu', dan tatapolah 'perilaku', yang dipimpin oleh Kuncén serta didampingi Lebé, dan Punduh. (Suryani NS, 2020 \& 2021).

\section{SIMPULAN}

Butir-butir Pancasila dalam teks naskah Sunda Kuno abad XVI Masehi, dikenal dengan sebutan Panca Tata Gatra, terdiri atas: 1) Adanya lima kewajiban untuk meyakini dan percaya terhadap Sang Manon, sebagai pencipta jagat raya; 2) Perilaku dan tindakan manusia yang sesuai dengan moral, serta memerlukan pertimbangan keadilan dan kebijaksanaan; 3) Lima selubung jagat raya, yang harus bersatu, dan tidak bisa dipisahkan satu sama lain untuk kelangsungan hidup di dunia; 4) Perekonomian diimplementasikan melalui mata pencaharian hidup sebagai petani, ahli perang, bangsawan termasuk alim ulama, dan raja/pemimpin pemegang tahta kekuasaan 5) Tiga penentu kebijakan dalam keadilan berbangsa dan bernegara. Panca Tata Gatra dimaksud, sejalan dengan kelima butir Pancasila yang kini digunakan sebagai dasar negara Republik Indonesia.

Butir-butir Pancasila, berkaitan dengan pelindung dan pendamai jagat raya, disesuaikan dengan letak dan kedudukan arah mata angin, yang memiliki warnanya masing-masing, dikenal dengan sebutan lima kemakmuran bagi seluruh negeri, dan dijaga oleh para dewa dimaksud, dengan sebutan dalam teks naskah Sanghiyang Wuku Lima Di Bwana, Halimpu Ikang Désa Kabéh, yakni, : 1) Arah timur, berwarna

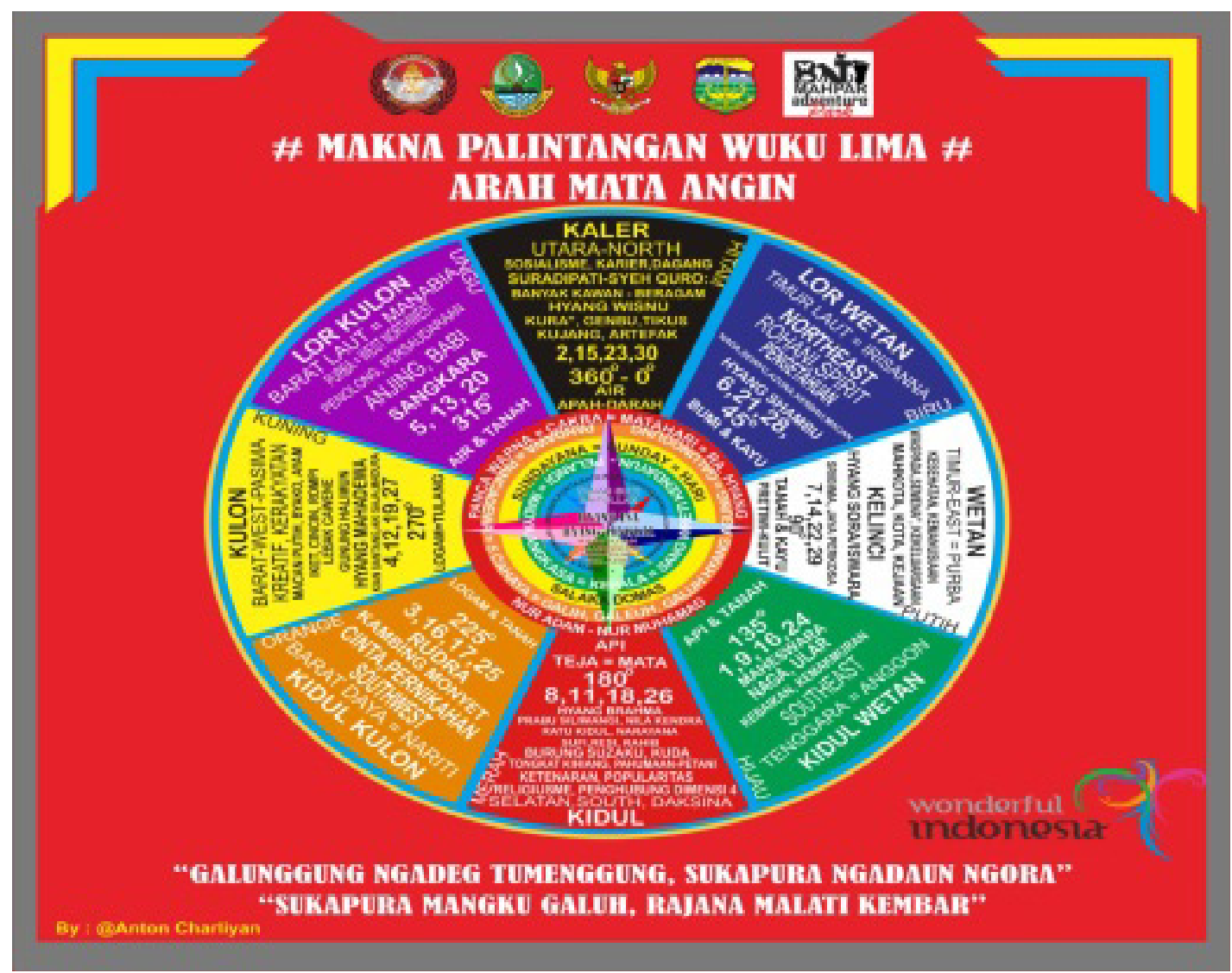

Sumber: Anton Charliyan, 2019 \& Suryani NS, 2019

Gambar 3. Makna Palintangan Wuku Lima. 
putih, bertempat di kahyangan, diduduki oleh Isora; 2) Arah selatan, berwana merah, ditempati Hyang Brahma; 3) Arah barat, berwarna kuning, ditempati Hyang Mahadewa; 4) Arah sebelah utara, berwarna hitam, ditempati Hyang Wisnu; 5) Arah tengah, berwarna aneka macam, ditempati Hyang Siwa.

Manusia berdasarkan naskah Sunda kuno abad XVI Masehi menempati keempat sila horisontal dalam Pancasila. Manusia bersifat monodualisme. Sila kedua, ketiga, keempat, dan kelima butir-butir Pancasila, yang mengacu kepada sila Ketuhanan Yang Mahaesa. Demikian juga dengan gagasan Panca Tata Gatra, yang gagasan butir dua sampai lima tertuju kepada Sembah Ing Hulun di Sanghyang Panca Tatagatra 'Adanya kewajiban meyakini dan percaya kepada Sang Pencipta'. Hal ini pun selaras dengan teks $S R D$, yang mengungkapkan bahwa semua benda dan makhluk di mayapada ini diciptakan dan bersumber dari Sanghyang Tunggal (Yang Mahaesa).

\section{UCAPAN TERIMA KASIH}

Alhamdulillah tulisan ini selesai, berkat limpahan karunia dari Tuhan Yang Mahakuasa, melalui kesehatan, ketekunan, dan kesabaran. Terima kasih kami ucapkan kepada Rektor, Direktur PPM, Dekan Fakultas Ilmu Budaya Universitas Padjadjaran, yang telah memberikan dukungan dan semangat untuk terus berkiprah melalui berbagai tulisan, baik di jurnal nasional maupun internasional bereputasi, serta buku dan majalah. Terima kasih pula atas kerja samanya untuk masyarakat Kampung Naga dan Baduy serta Kabuyutan Ciburuy yang telah membantu selama kegiatan penelitian dan penulisan artikel ini berlangsung. Semoga kebaikan Ibu/Bapak/ Saudara dibalas dengan kebaikan yang setimpal oleh Allah SWT. Aamiin YRA.

\section{DAFTAR PUSTAKA}

Atja \& Danasasmita, S. (1981). Sanghyang Siksakanda ng Karesian (Naskah Sunda Kuno. Bandung: Proyek Pengembangan Permuseumam Jawa Barat.

Bakker, A. (1983). Kosmologi \& Ekologi: Filsafat tentang Kosmos sebagai Rumah tangga Manusia. Yogyakarta: Kanisius.

Charliyan, A. (2015). Master Leadership. Menyingkap 99 Rahasia Kearifan Lokal Nusantara Soal Kepemimpinan. Depok: Solusi Publishing. 2443-2067.

Darsa, U.A, Sumarlina, E.S.N. \& Permana, R.S.M. (2020). Existence of Sundanese Manuscripts as a Form of Intellectual Tradition in the
Ciletuh Geopark Area. Jurnal Ilmiah Peuradeun. 8(2), 259-278. DOI: https://doi. org/10.26811/peuradeun.v8i2.369

Ekadjati, E.S. (2007). Nu Maranggung Dina Sajarah Sunda. Bandung: Pusat Studi Sunda.

Ekadjati, E.S. \& Darsa U.A. (2007). Kosmologis Sunda. Bandung: Pusat Studi Sunda.

Suryani, E.N.S. (2016a). Budaya Sunda dalam Untaian Masa. Bandung: UnpadPress.

Suryani, E.N.S. (2015). Pancasila dalam Naskah Sunda Buhun (artikel). Bandung: Pikiran Rakyat. Link: https://tandamatabdg.wordpress. com/2015/06/27/pancasila-dalam-naskahsunda-buhun/

Suryani, E.N.S. (2016d). Kosmologis dalam Naskah Sanghyang Raga Dewata (artikel). Tasikmalaya: Radar Tasikmalaya.

Suryani, E.N.S. (2018a). Mengungkap Serpihan Terpendam Budaya Kampung Naga. Bandung: Situ Seni \& PT. Raness Media Rancage.

Suryani, E.N.S. (2018b). Senarai Kearifan Lokal Budaya dalam Media Massa Cetak Jilid 1 \& 2.. Bandung: PT. Raness Media Rancage.

Suryani, E.N.S., Permana, R.S.M. \& Darsa, U.A. (2020). Tata Ruang Kosmologis Masyarakat Adat Kampung Naga berbasis Naskah Sunda Kuno, LOKABASA, 11, (1), 22-28. doi: 10.17509/jlb.v11i1.25163.

Suryani E.NS., Permana, R.S.M \& Darsa, U.A. (2019). The Role of Sundanese Letters as the One of Identity and Language Preserver," in Proceedings of the 2nd Konferensi BIPA Tahunan by Postgraduate Program of Javanese Literature and Language Education in Collaboration with Association of Indonesian Language and Literature Lecturers, KEBIPAAN, 9 November, 2019, Surakarta, Central Java, In, 2020, pp. 1-7, doi: 10.4108/eai.9-11-2019.2295037.

Sumarlina, E.S.N. (2020). Pandangan Hidup, Etika Berpolitik, dan Kepemimpinan dalam Naskah Sunda Kuno Bandung: PT. Raness Media Rancage.

Udasmoro, W. (2012). Pengembaraan Serat Centhini Dalam Centhini Les Chants De L'île À Dormir Debout Dan Ia Yang Memikul Raganya: Interpretasi, Inovasi Dan Distorsi Dalam Penerjemahan, Sosiohumaniora, 14, (1), 52-62. 